\title{
Language and Manipulation: A Critical Discourse Analysis of All Progressive Congress (APC) and People's Democratic Party's (PDP) War of Words
}

\author{
Ebere Celina Krisagbedo \\ Use of English Unit, School of General Studies, University of Nigeria, Nsukka, Nigeria \\ Jacinta Ukamaka Eze \\ Department of Linguistics, Igbo and Other Nigerian Languages, University of Nigeria, Nsukka, Nigeria \\ Juliana Ginika Mamah \\ Department of Linguistics, Igbo and Other Nigerian Languages, University of Nigeria, Nsukka, Nigeria

\begin{abstract}
This paper examines the crucial role language plays in manipulating the act of discourse comprehension as a means of constructing mental models meant to effect mind control against the people's best interests. To achieve this, the study utilises the rich resources of critical discourse analysis (CDA) precisely, the socio-cognitive framework, to analyse media political discourse within the Nigerian context. A number of discourses that hinge on the APC and PDP's war of words over the issue of corruption extracted from the online editions of Nigerian newspapers constitute the data used for the study. The result of the data analysis indicates that Nigerian politicians consciously indulge in positive self-presentation and negative-other presentation by making use of the ideological square in the portrayal of self for the sole purpose of imposing their ideological designs on the entire populace in order to gain political dominance. Through the ideological square, each of the political parties aims at emphasizing the positive sides of its actions and the negative aspects of the other party while de-emphasizing its negative activities and the positive sides of the other through the use of manipulative language. Such manipulative use of language disables the people's critical thinking for the manipulators' benefit.
\end{abstract}

Index Terms — manipulation, critical discourse analysis, ideological square, positive self

\section{INTRODUCTION}

Critical Discourse Analysis (CDA) as a theory captures the use of language to manipulate, subjugate and create inequality within a social system through mind control and the creation of ideologies that serve the interest of the elite and political class. CDA distinguishes itself from other approaches to discourse analysis by virtue of its focus on "the relations between discourse, power, dominance, social inequality and the position of the discourse analyst in such relationships" (Nicole, 2020, p. 1079). It is an integrative method of discourse study developed through a union of divergent theories. Its establishment is strongly rooted in the perception that 'text and talk' are key players in initiation and legitimisation of 'inequality, injustice, and oppression' within the social order (www.grim.com). It utilises different approaches to show how these societal ills are perpetrated by creating awareness on the manipulative aspect of language use in society, and canvasses specifically for positive adjustments through its conclusions (www.grim.com).

CDA in Fairclough's (1993) view is an offshoot of discourse analysis, which systematically investigates the opaque relationships that exist between discursive practices and socio-cultural structures with the purpose of establishing how discursive practices, events and texts emerge and are ideologically shaped by power and power struggles as manifested in language. "CDA not only focuses on language and language use, but also on the linguistic characteristics of social and cultural processes. CDA follows a critical approach to social problems in its endeavour to make explicit power relationships which are frequently hidden" (hdl.handle.net). One of the major concerns of CDA is to make transparent the network of opacity that connects discourse practices and structures whose comprehension would have otherwise eluded a layperson (Sheyholislami, 2001). It arrives at conclusions, which are of utmost utilitarian value within a number of contexts in human existence (Fairclough and Wodak, 1997). In CDA, social cognition is of utmost importance as it bridges the gap between discourse and society. van Dijk (1993) argues:

In order to relate discourse and society, and hence discourse and the reproduction of dominance and inequality, we need to examine in detail the role of social representations in the minds of social actors. More specifically, we hope to show that social cognition is the necessary theoretical (and empirical) 
interface, if not the missing link, between discourse and dominance. In our opinion, neglect of such social cognitions has been one of the major theoretical shortcomings of most work in critical linguistics and discourse analysis (p. 252).

CDA is problem-oriented; it addresses social problems especially as it concerns the role discourse plays in the production and re-production of power abuse and dominance (van Dijk 2001, p. 96). Being critical in its approach involves the role the analyst plays in trying to lay bare the unequal power relationship in the society as rooted in discourse (Rogers 2004, p. 3). A critical discourse analyst tends to raise the consciousness of language users to the nuances of language use, which conceal the full import of the manipulative tendencies embedded in discursive structures. This is necessary because such manipulative tendencies are often enshrouded in ambivalent use of language for the benefit of the manipulator as evident in political discourse where politicians struggle to dominate the polity at all costs. Nigerian politicians are not left out in such struggle and are always trying to outdo one another in controlling the mind of the people. Each political party wants to increase its popularity with the voters by castigating opposition parties and presenting itself as the credible machinery through which the people will be saved.

The ideological differences that characterise the two dominant political parties in Nigeria - All Progressive Congress (APC) and People's Democratic Party (PDP) - have thrown the parties into verbal conflicts virtually over every subject of national concern, but prominent among such contentious topics is the issue of corruption. Corruption has in historical and contemporary times proved to be the bane of Nigerian society and has given both past and present administrations a lot of concern. It is viewed as the "single greatest obstacle preventing Nigeria from achieving its enormous potential" (Page 2018, p. 1). Of all the social ills that rock Nigeria as a country, corruption ranks highest and the trend has even sky-rocketed in recent times. It has actually proved resistant to all the strategies mapped out by successive administrations to suppress its tenacity. According to Transparency International in the 2018 Corruption Perception Index, Nigeria is the 144th least corrupt country out of the 175 countries rated. This shows that the war against corruption declared by President Muhammad Buhari is yet to make significant positive impact.

It is therefore not surprising that the two parties that have been in charge of the Nigerian affairs for the past two decades either as the ruling or the opposition party are accusing and counter-accusing each other of being corrupt at different levels and on various accounts; each trying to outdo the other in the verbal tirade. In doing that, each of the parties tries to present self as the saint while the other is painted in back as the devil that oils the wheel of corruption in the country and expect Nigerians to view the situation in the same way.

\section{Language and Manipulation}

Language as a means of communication is liable to human appropriation for different purposes. What man does with language is innumerable ranging from the transactional activities to the interactional concerns depending on the situation at hand (Brown \&Yule, 1983). The manipulative power of language manifests at the level of discourse. The term, discourse is viewed

by structuralists as a unit of language that extends beyond the sentence level while the functionalists see it as language use and as such is interested in both the spoken and written forms of Language. Discourse can be used for manipulative purposes in different spheres of life especially in the political arena. Manipulation as a concept has both positive and negative connotations. On the positive side, it is seen as persuasion where people are meant to process what they are being told and make decisions based on personal assessment. The negative aspect implies domination.

According to van Dijk, "manipulation implies the exercise of a form of illegitimate influence by means of discourse: manipulators make others believe or do things that are in the interest of the manipulator, and against the best interests of the manipulated" (www.scribd.com). It is an established fact that language and thought are intertwined to the extent that language controls the human cognitive process giving room for the act of manipulation to take place. According to Akwanya (2005) "Thought, of course, never lets itself be seen, and language is one of the ways in which it may be analysed, through the analysis of discourse, because of the bonding with thought whereby language transmutes into discourse" (p. 8). It is the powerful groups and individuals in the society that exercise mind control and consequently manipulates the less powerful. Being in a position of power can come in different forms; by virtue of one's profession, position in government, physical strength, and financial status among others. The political class is the major disciples of the game of mind control within a given society as they have access to the media through which they sell their ideologies to the masses.

In this paper, we explore the extent to which language is exploited as a tool of manipulation by politicians in Nigeria to impose their preferred mental models on the people and by extension advance their sectarian interests. We seek to characterize these discourse practices and structures and the underlying manipulative tendencies of the social actors (in this context, the APC and PDP) from the theoretical prism of CDA. We intend to address the research problem, which centres on the manipulative use of language by political actors for advancing self-serving interests and its adverse effect on the common good of the people. The central objective is to account for the manipulative strategies of the political actors and the need for the populace to develop critical thinking that would predispose them to probe beneath the veil of hidden agenda implicit in political communication.

In the next sections, we shall carry out a review of related literature, examine CDA and how we intend to enlist its theoretical resources as framework in analysing the data elicited from the online editions of selected newspapers. 


\section{LITERATURE REVIEW}

Critical Discourse analysis is a multifaceted approach to the study of discourse and yields itself to multiplicity of applications in different fields of study. In this section, samples of such applications will be reviewed in order to properly situate the present study. van Dijk (2006) explores manipulation as a key notion in critical discourse analysis. He accounts for manipulation in terms of social power abuse through a tripartite approach that comprises discourse, cognition and society. The three are inter-related and significantly influence ideological formation and advancement for the interest of key political actors. This he illustrates through the "analysis of a speech made by Tony Blair in the House of commons justifying the part played by the UK in the US led war against Iraq in 2003" and noted that there was conscious use of ideological polarisation typified in positive self-presentation and negative other-presentation (www. scribd.com).

Rotimi (2007) examines language, ideology and power relations in Nigerian newspaper headlines with the aim of ascertaining the ideological foundations of their construction. The study discovers that the headlines were ideologically driven, showcasing a bi-directional division along the line of those whose interests are protected and those at the receiving end of the ideologies propagated. This reveals the fact that newspaper headlines are tools in the hands of the editors who manipulate them to capture and sustain the interest of readers on issues of national concern.

Albert \& Salem (2013) investigate the viability of utilising critical discourse analysis as a tool for theory advancement in social media. The work dwells much on the tenets of different approaches in CDA that border on the analysis of social issues and established a relationship between the Realist Principle in social media and Relational Approach in CDA. The argument being that since social media is a discursive structure that epitomises social issues, there is the need to align aspects of CDA in the study of information systems. This could be useful in the study of some phenomenon within social media such as social movements, cyber bullying and online sexual predation among others.

Ines (2014) carries out a critical discourse analysis of self-presentation as entailed in the cognitive processes associated with 'we'. The thrust of the work is the exploration of the relationship that exist between discursive structures and self-presentation through two newspaper articles co-authored by two heads of state, President Barack Obama and Nicholas Sarkozy dealing with the events in Libya. The analysis was carried out using CDA together with the process of transitivity as enunciated by Halliday's Systemic Functional Linguistics (SFL). The result indicates that the transitivity patterning and the cognitive process disclose a preponderance of positive self-presentation, where 'we', that is the writers, are presented as 'one coherent and dissidence-free group' that share common understanding of the issue at stake (Ines 2014, p.557).

Ehineni (2014) utilises the resources of critical Discourse Analysis to assess the ideological undertones in the use of the modals by the Nigerian Politicians in the process of manifesto presentations. The data used for the study were the manifestos of two Nigerian politicians; "Dr. Olusegun Mimiko of the Labour Party (LP) and Barrister Rotimi Akeredolu of the Action Congress of Nigeria" (CAN). Both were the 2012 gubernatorial candidates in Ondo state. It was established that the modal auxiliary verbs such as 'will', 'shall', 'must', 'can' were utilised by the politicians in making promises while seeking the peoples' support. Beyond that, the modals are used by the politicians as tools for manipulation and ideological advancement (www.peopleandpolitics.com.ng).

Ugwuona (2015) examines Boko Haram as a discourse topic in Nigerian print media in the light of Critical Discourse Analysis. She drew the data from prominent Nigerian newspapers precisely, Daily sun, Newswatch and The Nation. The analysis lays bare the manipulative use of language inherent in the choice of words made by the commentators. They take different stand points as it concerns the menace of Boko Haram activities in Nigeria. Ugwuona (2015) opines that commentators within the Nigeria print media should desist from any form of manipulation of language that tends to support the terrorist group and embrace language that fosters peace and unity for the sustenance of national stability.

Ogunmuyiwa (2015) carries out a critical discourse analysis of corruption in presidential speeches using two presidential speeches of Umaru Musa Yar'Adua and Goodluck Jonathan as data. The framework adopted for the study is Halliday's Systems of Transitivity together with Fairclough's approach to CDA. The result of the analysis indicates that the Presidents used language in such a way that exonerate them from corruption and bring to light their commitment to fight corruption.

Yasemi \& Aghagolzadeh (2015) use van Dijk's framework to carry out a critical discourse analysis of 'Face to Face', a book written by Chris Redstone and Gille Cumingham with the aim of unveiling its integral constituents and the ideological perceptions represented therein. The result indicates that discursive elements such as power and cognitive models together with social structures as presented in the text combine to portray the ideological stand of the western societies rooted in capitalist system and racism.

Richard \& Nwuizug (2017) study the legal discourse within the confines of Critical Discourse Analysis with the intention of unraveling unequal power relationship exhibited in courtroom proceedings among the participants. The study made use of audio-recorded and personal observations of the legal transactions in a courtroom. The asymmetry in the power relationship discovered thereof indicates that the judge enjoys the greatest power followed by the examiners while the witnesses are mere passive participants in the process whose minds are to an extent controlled by the examiners. All these are evident through the use of language in the courtroom.

Awotayo (2018) studies the 'change' slogan in Nigerian political discourse within the framework of Critical Discourse Analysis. Wodak's Discourse Historical Approach was used to analyse selected presidential speeches and 
religious speeches of Muhammadu Buhari and Rev. Father Ejike Mbaka respectively. The 'change' slogan was discussed from the two contextual backgrounds and it was discovered that it is an ambiguous linguistic manipulation that serves ideological goals and as such requires an in-depth analysis to fathom the manipulative tendencies embedded in the slogan.

Suileman-shika (2019) uses Fairclough's approach to critical discourse analysis to study the morale-boosting songs and chants of soldiers in 14 Brigade Brracks, Ohafia in Abia state, Nigeria. The study analyses a number of songs and chants used by the soldiers. It discovers that the wordings are derived from a three-dimensional element emanating from the use of corrupt forms of words, subject matter and the injection of verbs and adverbs from the vernacular together with economy in the use of words for the soldiers' entertainment. The songs equally transcend the means of entertainment for the soldiers and coalesce into a unifying factor that affirms their conquest over fear of death and death by fear.

The studies reviewed show that Critical Discourse Analysis has the capability of accounting for varied forms of discourse from different points of view depending on the approach a writer chooses to adopt. Some writers have actually carried out studies on media political discourse in Nigeria using the crucible of CDA, but none has examined the focal point of the present paper which is; the manipulative use of language entailed in PDP and APC's war of words in Nigeria over the issue of corruption.

\section{THEORETICAL FRAMEWORK}

The theoretical framework adopted for this study is Critical Discourse Analysis (CDA). CDA is not primarily a linguistic theory but a multidisciplinary framework that combines approaches from different fields of study that have interest in human behaviour as well as cognitive processes such as sociology, anthropology, psychology and linguistics to mention but these. According to Amoussou and Allagbe, (2018) "method of analysis in CDA is highly dependent on the nature of the social problem under investigation and the disciplinary background of the anlyst" (p. 14). Thus, a number of scholars has propounded some principles considered as the bedrock of CDA from varying perspectives. Prominent among them are the works of van Dijk (1993), "Fairclough (1995), Fairclough \& Wodak (1997), Wodak \& Meyer (2001), Hammersley (1997), Jorgenson \& Phillips (2000), Pennycook (1994), Weiss \& Wodak (2003)” among others (brisjast.com).

In view of the multi-faceted nature of CDA, there are a number of approaches within the theory; Fairclough's sociocultural approach, van Dijk's socio-cognitive approach and Wodak's discourse-historical approach. Each of the approaches has its peculiarities and distinguishing attributes. For the purpose of the present study, van Dijk's sociocognitive approach is to be used. The socio-cognitive framework utilises a tripartite structure or what he termed the 'triangulation frame' comprising discourse, cognition and society (van Dijk 2006, p. 360). He defends the relevance of the three components and established their relationship by maintaining that 'discourse analytical approach' is necessitated by the fact that manipulation occurs through 'text and talk'. Going further, he states that the manipulated are humans whose cognitive processes are played on for manipulation to take place, hence the cognitive account. Finally, the social aspect takes care of the fact that manipulation takes place through 'talk in interaction' and implies power and power abuse (van Dijk, 2006, p. 360). This approach conceptualises discourse as a social praxis that stems from ideologies as well as levels of power relationships integrated in discourse. He accounts for social power in terms of mind control. Ideologically, mind control can be achieved in discourse through the strategy of positive selfpresentation and negative other-presentation (van Dijk, 2006, p. 131).

This study uses van Dijk's (1993) concept of the ideological square as a major tool for the data analysis. The ideological square consists of the semantic macro strategies advanced by van Dijk which makes explicit the features for positive self-presentation and negative other-presentation. The ideological square emphasises the positive 'Us' and deemphasises the positive 'Them'; correspondingly, it emphasizes the negative 'Them' and deemphasises the negative 'Us' (paulslals.org.uk). Positive self-presentation and negative other-presentation are two relative strategies (van Dijk, 1993). These two strategies are interested on participants as social groups rather than individuals (van Dijk, 2009). Ideology is a strong determinant in the organisation of discourse "in terms of social representation of us versus them; that is, what we are, what we typically do, what our aims and values are in relation to them, and what they are, what they typically do, what their aims and values are in relation to us" (Ines 2014, p. 540). The analysis of ideological square is made up of these four moves:

i. Express/emphasise information that is 'positive' about us.

ii. Express/emphasise information that is 'negative' about them.

iii. Suppress/de-emphasise information that is 'negative' about us.

iv. Suppress/de-emphasise information that is 'positive' about them (mafiadoc.com).

\section{DATA}

This study makes use of the data generated from online editions of Nigerian Newspapers. In this section we bring together a number of speech acts that showcase the APC and PDP's war of words. The data is presented in the form of 
adjacency pairs showcasing accusations and counter accusations of corrupt practices among the two political parties under study.

\section{A. Extract}

(4.1a) "It is disheartening that instead of President Buhari to seek ways to recover the over N14tn looted by APC leaders and the cabal in the presidency, Mr. President is seeking to inflict more pains on distraught Nigerians by imposing new taxes on them in the coming year"... "The PDP Presidential Campaign Organisation condemns as punitive, the plans by the President Buhari to impose on Nigerians who are already overburdened, impoverished and pauperized by his incompetent, insensitive, uncaring, vindictive and corrupt administration." (www.vanguardngr.com)

(4.1b) "The national chairman of the APC, Adams Oshiomole, said that the party's three years in power had remedied the 16 wasteful years of the PDP" (PDP, APC trade words over looting, mismanagement December 23,2018 Success Nwogu and Umar Muhammed - http://punchng.com/pdp-apc-tradewordsover-looting-mismanagement)

\section{B. Extract}

(4.2a) "The PDP National Publicity Secretary, Kola Ologbodiyan ...challenged the APC to address the cases of the N21billion allegedly found in the residence of Daura among others. They should respond to humongous allegations of President Buhari's ally, the sacked DSS DG, Daura's N21billion cash and other sundry items including PVCs allegedly found in his house. They should tell Nigerians how the Finance Minister, Mrs. Kemi Adeosun escaped National Service and forged exemption certificate to cover up. Yet Mr. Integrity did not find anything wrong with that...." (sunnewsonline.com).

( $4.2 \mathrm{~b}$ i) 'It is truly amazing that the party of a failed government which held the country prostrate for 16years, stole, wasted and misappropriated our abundant resources will have the audacity to make comments on the current administration that within three years is clearing the rot left after the PDP's misrule." - Acting National Publicity Secretary, Yekini Nabena (sunnewsonline.com).

(4.2b ii) "Instead of apologizing profusely for their gang rape of the nation, the PDP seeks to present itself before Nigerians in 2019 to seek a return to their stealing. The PDP should understand that Nigerians cannot forget in a hurry how the country was destroyed by the PDP's gang of pen robbers." (sunnewsonline.com)

(4.2b iii) "The PDP should explain to Nigerians under which administration a governor who was set free in many courts in Nigeria on charges of corruption and money laundering but was tried and jailed in the United Kingdom" (sunnewsonline.com).

(4.2b iv) "Is it not ironic that the PDP preaches about corruption in the oil sector when it in act oversaw record pillage, maladministration and disrepair of the oil sector when it held sway" (sunnewsonline.com).

$(4.2 \mathrm{~b} \mathrm{v})$ "How many millions of dollars did he say was not remitted to the nation's coffers on regular basis? The PDP may also explain the fuel subsidy scandals and how billions of the country's funds went into private pockets; the massive seizures of properties and cash from public officers who served in the PDP Government" (sunnewsonline.com).

(4.2b vi) "In 2015, Nigerians voted massively for the establishment of a truly progressive government to check the shocking level of impunity, corruption, disregard for the rule of law and other deplorable undemocratic practices which previously defined our national life. The APC assures all Nigerians that the President hold sacred this collective trust. Despite spirited efforts to discredit ongoing anti-corruption efforts, the war against graft is being won. An oftenoverlooked major achievement of the anti-corruption war is that President Buhari has brought the issue of corruption to the heart of national consciousness. Under President Buhari, the country has never had it so good. Yearly remittances by the Joint Admissions and Matriculations Board (JAMB) have been in billions of Naira, over and above what PDP governments remitted in 16 years; increasing yearly revenue from the Customs Service; within three years and despite low oil prices, execution of massive road and rail infrastructure our foreign reserves have grown to over $\$ 47$ billion about $\$ 4$ billion more than that of South Africa.” (http://www.sunnewsonline.com/apc-pdp-fight-alleged-corruption/)

\section{Extract 4.3}

(4.3 a) "And the corruption that they put on our neck, we have shed all the corrupt party leaders to the APC and I can say it. So, the PDP is free of corruption; APC is the mother of corruption for the past 16 years" said Kunle Okunlola, the House of Representatives candidate for the PDP for Ikeja Federal Constituency (www.newsbreak.ng).

\section{Extract 4.4}

(4.4ai) While the state's Director of Media and Publicity of the Atiku/Obi PDP Presidential Campaign Council, Lere Olayinka, accused the APC of plotting massive vote buying for the Saturday Presidential and National Assembly elections, alleging that a sum of N112.5bn has been earmarked to buy projected 15 million votes at N7,500 per vote, APC's Director of Media for the state's Buhari/Osinbajo campaign council, Tai Akogun, has described the allegations as cruel and irresponsible, declaring that President Mohammadu Buhari was not only a man of integrity, who would never buy votes but also has performed creditably well to be given a second term by Nigerians on a platter of gold"( dailypost.ng).

(4.4aii) 'The PDP said, "Their plots are in two folds. While they are forging ahead with their clandestine plot to compromise the Independent National Electoral Commission (INEC) and rig the elections by getting the electoral 
commission to produce two sets of result sheets (Form EC8A) for some selected polling units across the country, they are also plotting massive vote buying. Urging Nigerians to reject vote buying, the security to be fair and its party agents to protect their votes, the PDP also alleged that security agents have been instructed to provide cover for all APC stalwarts to be assigned with the responsibility of ascertaining voters' compliance and making payments to voters who complied"(dailypost.ng).

(4.4bi) 'Reacting to PDP's allegations, Akogun said: "Everybody knows Buhari as a man of integrity, by this time four years ago, we were already hearing about raising huge funds for former President Jonathan's campaign, where contractors are raising huge funds, but now you can't hear of any contractors doing that, is this kind of President the one that would waste N112 billion for campaign?" (dailypost.ng).

(4.4bii) "Fayemi as our governor is not a frivolous person; he is not a kind of person that will use such money to buy votes. This is a cruel and irresponsible allegation, the PDP is only crying foul because they know they are losing the coming polls. They know that 14,000 Ekiti youth who benefitted immensely from N-power and those who also benefitted from Tradermoni will vote massively for Buhari. In Ekiti alone, the railway line that Buhari has built, the federal secretariat almost at completion at the new Iyin Road and the housing scheme in agric Olope, all in Ado Ekiti is our own N112 billion which will attract votes for Buhari. We challenge the PDP to show us what former president Goodluck Jonathan did for Ekiti in his time. Buhari doesn't need to buy votes because he has performed creditably well.'(2019 election: APC, PDP in war of words over vote buying, rigging allegations by Ani Emmanuel, February 12, 2019 (dailypost.ng)

\section{E. Extract 4.5}

(5a) "... the presidential candidate of the PDP, Alhaji Abubakar, called out President Buhari over certain allegations of corrupt practices which the president allegedly condones in his government" (nigeriastandardnewspaper.com).

(4.5bi) "Whilst we have repeatedly addressed each and every of the instances cited by him to show the transparent nature of the government, it is shocking that the presidential candidate of the main opposition has refused to issue a personal statement up till this minute clarifying in details his record of crass corruption and abuse of office" (nigeriastandardnewspaper.com).

(4.5bii) "Others include diverting \$125million from a public development trust fund into his personal business according to a probe ordered by former president Olusegun Obasanjo, and an indictment by a senate subcommittee investigating the PTDF that he abused his office by aiding and abetting the diversion of public funds in the sum of $\$ 145$ million as loans to his friends. This report was subject to full blown investigation by the EFCC which actually recommended his prosecution in a court of law (www.vanguardngr.com).

\section{DATA ANALYSIS}

van Dijk's socio-cognitive framework not only outlines the relationship that exist within discourse, cognition and society, but goes further to expose the gimmicks employed by the elite, particularly politicians in manipulating the mental models of the target group, which in the present case is the Nigerian masses. The constituents of the mental models are both personal and shared beliefs, which play significant roles in discourse cognition as it carries both personal and shared beliefs, but manipulators' target is always to gain "control of the shared social representations of groups of people because these social beliefs in turn control what people do and say in many situations and over a relatively long period" (repository.essex.ac.uk)). This analysis pays distinctive attention to the strategies that politicians utilise in influencing the socially-shared beliefs in their bid to impose the "preferred models" by intentionally emphasising certain information rather than others that may lead to a distorted understanding of issues at hand.

The strategies used to encourage the formation and advancement of such preferred models is to discursively stress those attributes of the models that are consistent with the manipulator's interest, that is, details of their good deeds while concealing those properties that are inconsistent with their interest especially their unpopular deeds (van Dijk, 2006, p. 367). This is done through self-presentation and the use of the ideological square; 'us' versus 'they' representing the ideological polarisation of the in-group and out-group as exemplified in the data elicited. The two political parties under study, APC and PDP, used self-presentation as well as ideological polarisation in their bid to gain popularity with the masses.

\section{Self-presentation and the Ideological Square}

The crux of the data elicited is the issue of corruption in Nigeria. Each of the political parties acknowledges that enormous corrupt practices are ongoing nationwide, but made use of positive self-presentation as evident from the data to absolve themselves of such vile tendencies. The parties and their allies present themselves as saints emphasising their good acts through their choice of words as evident in the speech acts made in (4.1b),(4.4bi),(4.4bii),(4.2bvi) where APC faithfully present the party as a messiah, a truly progressive government, that came to deliver the nation from the shocking level of impunity, which the past administration plunged the nation into, and its few years in power has actually performed the miracle of restoring the wasteful years of the past administration. The presidential candidate, Muhammadu Buhari was portrayed as a man of integrity who was at the helm of affairs of a transparent government and whose performance would earn a second term on a platter of gold. Dr. Fayemi, the Governor of Ekiti State under same APC was described as not being frivolous and therefore could not engage in corrupt practices such as vote buying. 
His good works were then enumerated to include empowering the people through the N-power program and the 'Tradermoni' among others that would earn him the support of the voters. PDP, on the other hand, was not left out in the mind control game as one of its supporters made it clear that PDP was free from corruption in (4.3a) above.

The use of the ideological square is evident in the data as each of the political parties engages in discursive group polarization which entails; express/emphasise information that is 'positive' about us, express/emphasise information that is 'negative' about them, suppress/de-emphasise information that is 'negative' about us and suppress/de-emphasise information that is 'positive' about them (Jamie, 2007, p. 209). The four moves are characterised by the use of positive words, statements, metaphors and selection of topics that emphasise 'our' positive side and the superiority of 'our' position in relation to 'Theirs' while what is positive about 'Them' is de-emphasised. Consequently, what is negative about 'Us' should be made vague likewise the positive about 'Them'.

These four moves are recurrent in the data, which appear as adjacency pairs where one party will lay an allegation against the other and the other will refute it and take recourse to counter allegation. In (4.1a), the PDP portrays the APC-led federal government in Nigeria as a corrupt, insensitive, uncaring, vindictive, administration that has overburdened, impoverished and pauperized Nigerians. APC retaliated by referring to the 16 years of PDP government as wasteful years. The trend continues in (4.2a) where PDP refers to President Buhari ironically as 'Mr. integrity' and urges him to respond to corrupt cases of money laundering and certificate forgery trailing his administration. APC responded in (4.2bi-vi) by reeling out many cases of corruption involving PDP especially during the past administration using negative metaphors that invoke repugnant imageries. PDP was portrayed as 'gang of pen robbers' that 'gangraped the nation' through many instances of corrupt practices. As if that was not enough, they described the PDP presidential candidate as 'one of the notorious cases of money laundering in the world' in (4.5ai). PDP equally asserted that they have shed all their corrupt leaders to APC maintaining that APC is the mother of corruption.

Throughout the political discourse from which the data was elicited there is a recurrent pattern of positive selfpresentation and negative other-presentation. The in-group will always present itself as a saint while the out-group is the devil that oils the wheel of corruption in the nation, all in the bid to manipulate and get more voters. With such trend, realities are distorted and the people are fed with biased information for purpose of imposing the politician's preferred mental models on them.

\section{Discussion OF FINDINGS}

In line with van Dijk's socio-cognitive approach to CDA, there are different discursive strategies as revealed by the data through which the politicians impose preferred mental models on the people for manipulative purposes. These strategies as yielded by the data are self-presentation, ideological polarisation, the use of metaphors, and pronouns.

\section{(a)Self-presentation}

In-groups engage in positive self-presentation as evident from the data. Each of the parties under study showcased the positive aspects of their interest in explicit terms that leave the reader with positive mental models of the parties with the intention of getting wider support within the polity. Instances of such self-presentations are as follows:

(i)Under President Buhari, the country has never had it so good...." (Yekini Nabena APC Acting National Publicity Secretary)

(ii) "Fayemi as our governor is not a frivolous person... Yekini Nabena

(iii) President Mohammadu Buhari was not only a man of integrity, who would never buy votes but also has performed creditably well to be given a second term by Nigerians on a platter of gold...." ( dailypost.ng)

(iv) Within three years and despite low oil prices, execution of massive road and rail infrastructure, our foreign reserves have grown to over $\$ 47$ billion - about $\$ 4$ billion more than that of South Africa... Festus Keyamo (sunnewsonline.com.)

(v) PDP is free of corruption... Kunle Okunlola (the House of Representatives candidate for the PDP for Ikeja Federal Constituency)

\section{(b) Ideological Polarisation - us versus them}

The two political parties made use of the ideological square; 'us' versus 'them' representing the ideological polarisation of the in-group and out-group as a discursive strategy in the political discourse under study. Here, self or the in-group is presented positively while the out-group is given a negative presentation. Hence, 'we' and all that concerns 'us' are good while 'them' and all they stand for are bad. As noted earlier, the ideological polarisation is characterised by the use of positive words, statements, metaphors and selection of topics that emphasise 'our' positive side and the superiority of 'our' position in relation to 'theirs' while what is positive about 'them' is de-emphasised. Consequently, what is negative about 'Us' should be made vague likewise the positive about 'Them'. This manipulative tendency is made manifest in the adjacency pairs that depict accusations and denials and then counter accusations in the war of words as evident in the data elicited. Instances of such are:

(i) "It is disheartening that instead of President Buhari to seek ways to recover the over N14tn looted by APC leaders and the cabal in the presidency, Mr. President is seeking to inflict more pains on distraught Nigerians by imposing new taxes on them in the coming year" ...PDP Presidential Campaign Organisation (www.vanguardngr.com).

(ii) “... the party's three years in power had remedied the 16 wasteful years of the PDP". The national chairman of the APC, Adams Oshiomole 
(iii) “...We challenge the APC to address the cases of the N21billion allegedly found in the residence of DSS, DG in Daura among others... The PDP National Publicity Secretary, Kola Ologbodiyan.

(iv)) 'It is truly amazing that the party of a failed government which held the country prostrate for 16years, stole, wasted and misappropriated our abundant resources will have the audacity to make comments on the current administration that within three years is clearing the rot left after the PDP's misrule." - Acting National Publicity Secretary, Yekini Nabena (sunnewsonline.com).

(v) "Their plots are in two folds. While they are forging ahead with their clandestine plot to compromise the Independent National Electoral Commission (INEC) and rig the elections by getting the electoral commission to produce two sets of result sheets (Form EC8A) for some selected polling units across the country, they are also plotting massive vote buying. Urging Nigerians to reject vote buying, the security to be fair and its party agents to protect their votes, the PDP also alleged that security agents have been instructed to provide cover for all APC stalwarts to be assigned with the responsibility of ascertaining voters' compliance and making payments to voters who complied"Lere Olayikan, Director of Media and Publicity of the Atiku/Obi PDP Presidential Campaign Council (dailypost.ng).

(vi) "Everybody knows Buhari as a man of integrity, by this time four years ago, we were already hearing about raising huge funds for former President Jonathan's campaign, where contractors are raising huge funds, but now you can't hear of any contractors doing that, is this kind of President the one that would waste N112 billion for campaign?" (dailypost.ng).

(vii) “... the presidential candidate of the PDP, Alhaji Abubakar, called out President Buhari over certain allegations of corrupt practices which the president allegedly condones in his government" (www.vanguardngr.com).

(viii) "it is shocking that the presidential candidate of the main opposition has refused to issue a personal statement up till this minute clarifying in details his record of crass corruption and abuse of office... the U.S. congress in a report featured Atiku as one of the four notorious cases of money laundering in the world" (www.vanguardngr.com).

\section{(c)Metaphors}

The politicians equally made use of metaphors such as, 'gang-rape', 'gang of pen robbers' and 'mother of corruption' to generate loathsome and awful imageries about the out-group with the intention of destroying whatever good image the people may have about them (out-group). In doing that each of the parties is claiming superiority over the other with the aim of securing more votes during elections. This can be seen in the extracts below:

[1] "Instead of apologising profusely for their gang rape of the nation, the PDP seeks to present itself before Nigerians in 2019 to seek a return to their stealing. The PDP should understand that Nigerians cannot forget in a hurry how the country was destroyed by the PDP's gang of pen robbers" (thedefenderngr.com).

[2] "APC is the mother of corruption for the past 16 years" (https//punchng.com).

\section{(d) Pronouns}

The two political parties made use of pronouns in their manipulative venture; members of the in-group use $u s$, our, ours, we to represent themselves while they, their, theirs, them are used for the out-group. In the data, the use of the pronouns listed above is in line with the ideological square; us, our, ours, we are portrayed in good light while they, their, theirs, them have nothing good to offer. All the cases of corruption are always perpetrated by 'they' and not 'we' as can be seen in $i$-iii below.

(i) "They should respond to humongous allegations of President Buhari's ally, the sacked DSS DG, Daura's N21billion cash and other sundry items including PVCs allegedly found in his house" (sunnewsonline.com).

(ii) "They should tell Nigerians how the Finance Minister, Mrs. Kemi Adeosun escaped National Service and forged exemption certificate to cover up" (sunnewsonline.com).

(iii) "Their plots are in two folds. While they are forging ahead with their clandestine plot to compromise the Independent National Electoral Commission (INEC) and rig the elections by getting the electoral commission to produce two sets of result sheets (Form EC8A) for some selected polling units across the country, they are also plotting massive vote buying" (dailypost.ng).

\section{CONCLUSIONS}

In this paper, we have examined language as a tool of manipulation as evident in the discursive practices of key actors of the mainstream political parties in Nigeria that is, All Progressive Congress (APC) and People's Democratic Party (PDP). By enlisting the theoretical resources of van Dijk's (1993) socio-cognitive perspective of Critical Discourse Analysis (CDA), we sought to characterise the discourse relations of APC and PDP. The value of the sociocognitive framework of CDA derives not only from the fact that it is multidimensional subsuming social, cognitive, and discursive-semiotic phenomena, as Agbedo (2019) avers; it equally lends itself well to the critical goals of this study in that it goes beyond the façade of manipulative discourses to illuminate the mechanisms deployed by politicians to manipulate recipients' models, and demystify their deceptive discourses by deciphering their manifest and latent ideologies. Going by the results of the data analysis, it became obvious that the key actors from both sides of the political divide engaged one another in war of words over the contentious issue of corruption in Nigeria.

In the course of examining the "relationship between language and context, discourse and power, and the social, cultural, and political ideologies found in different types of discourse", it was revealed that the politicians consciously indulge in positive self-presentation and negative-other presentation by making use of the ideological square in the 
portrayal of self for the sole purpose of imposing their ideological designs on the entire populace for the sole purpose of advancing their peculiar sectarian interests(digitalcommons.hamline.edu). In this connection, self-presentation, ideological polarization, metaphors, and pronouns sufficed as premium discursive strategies. For van Dijk (1998, p. 2003), "these strategies and moves at various levels of discourse are hardly surprising because they implement the usual ideological square of discursive group polarization" one finds in all ideological discourse (www.scribd.com).

By exploring the relevance of socio-cognitive framework of CDA in the study of politicians' war of words as an aspect of political communication in the Nigerian media political discourse, we sought to prove a number of points; first, that the discursive component of the theory deals with the "many structures of ideological polarization between 'Us' and 'Them'; secondly, that such discourse structures are interpreted and explained in terms of underlying sociallyshared prejudices and ideologies and the ways they influence the mental models of individual language users; thirdly, that such discourses and their underlying cognitions are socially and politically functional in the (re)production of class domination and inequality by the dominant" political elite group against members of the Nigerian electorate, who are controlled by powerful ruling elite that have unfettered access to public discourse (journal.euser.org).

The unfolding scenario imposes urgent requirement on the Nigerian populace to develop critical thinking and see through the shenanigans of the manipulative dispositions of the politicians with a view to countering their deceptive inclinations and making informed choices in the course of exercising their electoral franchise.

\section{REFERENCES}

[1] Agbedo, C.U. (2019). Sounds of double speak in Nigerian media political discourse. In E.E. Mbah \& C. U. Agbedo (Eds). Sound Matters: A Festschrift in honour of Prof. Clara Ikekonwu. Nsukka: University of Nigeria Press Ltd.

[2] Akwanya, A. N. (2005). Language and the Habits of Thought 3rd ed. Enugu: New Generation Books.

[3] Albert, C. S. \& Salam, A.F. (2013). Critical Discourse Analysis: Towards Theories in Social Media. Proceedings of the Nineteenth Africa's Conference on information Systems.1-8.

[4] Amoussou, F. \& Allagbe, A. (2018). Principles, theories, and approaches to critical discourse analysis. International Journal on Studies in English Language and Literature 6(1), 11-18.

[5] Awotayo, O. B. (2018). "contextualizing "change": a critical discourse analysis of the "change" slogan in Nigerian Political Discourse (2014 to present)", Open Access Master's Thesis, Michigan Technological University. Retrieved from https://digitalcommons.mtu.edu/etdr/561/ on 24 April 2019.

[6] Brown, G. \& Yule G. (1983). Discourse Analysis. Cambridge, Cambridge UP.

[7] Ehineni, T.O. (2014). A Critical Discourse Analysis of Modals in Nigerian Political Manifestos. International Journal of Linguistics 6(3), 109-117.

[8] Fairclough, N. (1993). Critical discourse analysis and the commodification of public discourse. Discourse and Society 4(2), 133-168.

[9] Fairclough, N. (1995). Critical Discourse Analysis. London: Longman

[10] Fairclough, N. \& Wodak, R. (1997). Critical Discourse Analysis. In Discourse as Social Interaction, T. van Dijk, (Ed.) London: Sage. 258-84.

[11] Hammersley, M. (1997). On the Foundations of Critical Discourse Analysis. Language and Communication 17, $237-248$.

[12] http://www.dailypost.ng/

[13] http://www.sunnewsonline.com/

[14] https://www.vanguardngr.com/

[15] https://www.scribd,com/

[16] https://www.nigeriastandardnewspapers.com/

[17] https://www.mafiadoc.com/

[18] htttps://www.grim.com/

[19] https://www.hdl.handle.net/

[20] https://www.journal.euser.org/

[21] http://www.thedefenderngr.com/

[22] https://www.newsbreak.ng/

[23] https://paulsals.org.uksa/

[24] https://www.repository.essex.ac.uk/

[25] http://www.digitalcommons.hamline.edu/

[26] https://www.brisjat.com/

[27] https://www.peopleandpolitics.com.ng/

[28] http://punch.org.com/

[29] Ines, G. (2014). A Critical Discourse Analysis of Self-presentation through the use of cognitive processes Associated with 'we'. Journal of Language Teaching and Research, 5(3), 550-558

[30] Jamie, S. (2007). North Korea, South Korea, and 007 Die Another Day. Critical Discourse Studies 4(2), 207-235.

[31] Jorgensen, M. \& Phillips, L. (2000). Discourse Analysis as Theory. London: SAGE Publications.

[32] Nicole, M. .E. (2020). LGBTQ+ Civil Rights: Local Government efforts in Volatile Era. Public Administration Review 80(6), 107-1086.

[33] Ogunmuyiwa, H. O. (2015). A Critical Discourse Analysis of Corruption in Presidential Speeches. International Journal for Innovation Education and Research 2(12), 31-50.

[34] Page, M. T. (2018). A New Taxonomy for Corruption in Nigeria. Washington DC: Carnegie Endowment for International Peace.

[35] Pennycook, A. (1994). Incommensurable discourses? Applied Linguistics, (15), 115-138. 
[36] Sheyholislami, J. (2001). Yesterday's "separatists" are today's "resistance fighters": A Critical Discourse Analysis of the representation of Iraqi Kurds in The Globe and Mail and The New York Times. M.A. Dissertation. Carleton University, Ottawa, Canada.

[37] Richard, B. \& Nwuizu, S. S. (2017). A Critical Discourse Analysis of Courtroom Proceedings in Nigeria. International Journal of Arts and Humanities 6(4), 93-102.

[38] Rogers, R. (ed) (2004). An Introduction to Critical Discourse Analysis in Education, New Jersey: Lawrence Erlbaum.

[39] Rotimi, T. (2007). Language, Ideology and Power Relations in Nigerian Newspaper Headlines. Nebula 4(1), 218-245.

[40] Suileman-shika, M. (2019). A Critical Discourse Analysis of the Moral-Boosting Songs and Chants of Soldiers in 14 Brigade Barracks, Ohafia, Abia State of Nigeria. Journal of English and Cultural Studies 2(1). 19-32.

[41] Ugwuona, C. N. (2015). Boko Haram as a Discourse Topic in Nigerian Print Media. Journal of Culture, Society and Development 5, 53-57.

[42] svan Dijk, T.A. (1993). The principles of critical discourse analysis. Discourse and Society 4(2), 249-283.

[43] van Dijk T. A. (1998). Ideology: A Multidisciplinary Approach. London: Sage Publications.

[44] van Dijk, T. A. (2001). Critical Discourse Analysis. In D. Tannen, D. Schiffrin \& H. Hamilton (Eds.), Handbook of Discourse Analysis. (pp. 352-371). Oxford: Blackwell. Retrieved from http://www.discourses.org/ Retrieved: 12 April 2019.

[45] van Dijk, T.A. (2006). "Discourse and manipulation." Discourse and Society 17(2), 359-383.

[46] van Dijk, T. A. (2009). Critical discourse studies: A socio-cognitive approach. In R. Wodak \& M. Meyer (eds.) Methods of critical discourse analysis. London: Sage, 62-86.

[47] Weiss, G. \& Wodak, R. (Eds). (2003). Critical Discourse Analysis Theory and Interdisciplinarity. Palgrave: MaCMillan Ltd.

[48] Widdowson, H.G. (2000). On the Limitations of Linguistics Applied. Applied Linguistics 21(1), 3-25.

[49] Wodak, R. (2007). Pragmatics and critical discourse analysis: A cross-disciplinary inquiry. Pragmatics \& Cognition 15(1), 203-225.

[50] Wodak, R. \& Meyer M. (Eds.) (2001). Methods of Critical Discourse Analysis, London: SAGE Publications.

[51] Yasemi, K. \& Aghagolzadeh, F. (2015). Critical Discourse Analysis of Face to Face Book by van Dijk Framework. Magnet Research Report 3 (2), 627-636.

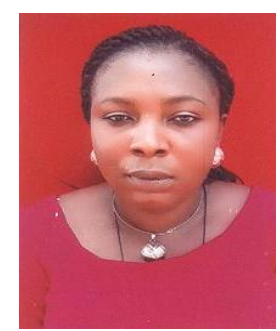

Ebere Celina Krisagbedo is a lecturer in the Use of English Unit, School of General Studies, University of Nigeria, Nsukka. She was born in Orba, Udenu Local Government Area of Enugu State, Nigeria on June 5, 1979. She obtained her Master of Arts and Bachelor of Arts in English language from the Department of English and Literary Studies, University of Nigeria, Nsukka in 2004 and 2011 respectively. Currently, she is pursuing a Doctoral Degree in English (Pragmatics) in the same Department.

She has the following work experiences;

LITERATURE-IN- ENGLISH LANGUAGE TEACHER, Urban Boys' Secondary School, Nsukka during the 2005 National Youth Service Year; SENIOR ENGLISH LANUAGE TEACHER, St. Cyprians', Special Science School, Nsukka 2006-2008; SENIOR ENGLISH LANGUAGE TEACHER, St. Francis' Secondary School, Ovoko 2010-2015. She joined the services of the University of Nigeria, Nsukka in December 2015 as an ASSISTANT LECTURER and has risen to the rank of LECTURER I. Her research interests cut across different areas of language and linguistic researches including ESL, sociolinguistics, pragmatics, discourse analysis, and applied linguistics. She has a number of book chapters and scholarly articles in national and international journals to her credit.

Mrs. Krisagbedo is a member of the following professional bodies:

Teachers Registration Council of Nigeria (TRCN);

Linguistics Association of Nigeria (LAN);

English Scholars Association of Nigerian (ESAN)..

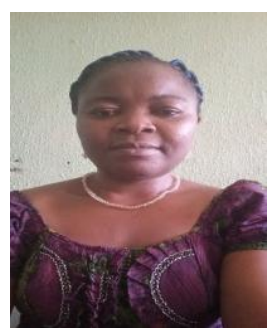

Jacinta Ukamaka Eze is a lecturer in the Department of Linguistics, Igbo and Other Nigerian Languages, University of Nigeria, Nsukka. She was born in Ovoko, Igbo- Eze South Local Government Area of Enugu State, Nigeria on $30^{\text {th }}$ July, 1980. She obtained her Master of Arts and Bachelor of Arts in Linguistics and Linguistics/Igbo respectively from the Department of Linguistics, Igbo and Other Nigerian Languages, University of Nigeria, Nsukka in 2019 and 2007 respectively. Currently, she is pursuing a Doctoral Degree in Linguistics (Sociolinguistics) in the same Department.

Jacinta specializes in Sociolinguistics, Pragmatics and Discourse analysis. Among the publications she coauthored are: Slang usage amongst students in urban areas: An insight of Warri metropolis. Igboscholars International Journal of Igboscholars Forum, Nigeria 13(1), 37 - 56; Hyponyms of insect in Ovoko Lect. Journal of Language Teaching and Reseach 11(6), 988 - 994.

Mrs. Jacinta is a member of Linguistic Association of Nigeria. 


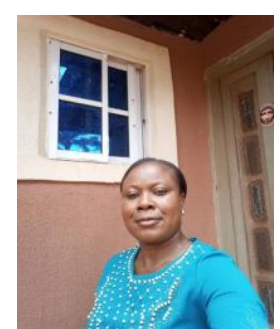

Juliana Ginika Mamah is a lecturer in the Department of Linguistics, Igbo and Other Nigerian Languages, University of Nigeria, Nsukka. She was born in Enugwu Ezike, Igbo- Eze North Local Government Area of Enugu State, Nigeria on $10^{\text {th }}$ August, 1980. She obtained her Master of Arts and Bachelor of Arts in Linguistics and Linguistics/Igbo respectively from the Department of Linguistics, Igbo and Other Nigerian Languages, University of Nigeria, Nsukka in 2019 and 2007 respectively. Currently, she is pursuing a Doctoral Degree in Linguistics (Psycholinguistics) in the same Department.

Juliana specializes in Psycholinguistics and Sociolinguistics. Among the publications she co-authored are: Slang usage amongst students in urban areas: An insight of Warri metropolis. Igboscholars International Journal of Igboscholars Forum, Nigeria 13(1), 37 - 56; documentation of endangered dialect of Igbo Language: Issues of greetings in Enugu-Ezike dialect. Journal of Language Teaching and Research 12(1), 120 -126. Mrs. Juliana is a member of Linguistic Association of Nigeria. 